\title{
Pharmacotherapy of diabetes mellitus in patients with heart failure - a nation-wide analysis of contemporary treatment
}

\author{
Marek Vichaa, Tomas Skala a, Libor Jelinek ${ }^{\mathrm{a}}$, Ludek Pavlua , Jiri Jarkovsky ${ }^{\mathrm{b}, c}$, Ladislav Dusek ${ }^{\mathrm{b}, c}$, Klara Benesova ${ }^{\mathrm{b}, \mathrm{c}}$, \\ Milos Taborsky ${ }^{a}$
}

\begin{abstract}
Aim. Retrospective national sub-analysis of antidiabetic pharmacotherapy in patients with diabetes mellitus (DM) and heart failure (HF) based on data reported to the National Register of Paid Health Services in the Czech Republic between 2012-2018.

Methodology and Results. In 2012, there were 75,022 patients with HF and DM (i.e. 42.5\% of patients with HF), 6 years later 117,265 (i.e. $41.0 \%$ of HF patients in 2018). The most represented antidiabetic drug was metformin (45.6\%). Of the insulins and analogues, glargine showed the largest positive trend (5.8\% 2012; 14.8\% 2018). Empagliflozin was the most prescribed SGLT-2 inhibitor (1.8\% in 2018). A decrease in prescribing was observed for saxagliptin (0.5\% 2012; $0.1 \% 2018$ ) and for sulfonylurea derivates - gliclazide (13.0\% 2012; 10.3\% in 2018) and glimepiride (12.9\% 2012; $9.0 \%$ 2018). Linagliptin was the most prescribed dipeptidyl peptidase inhibitor (0.7\% 2012; 6.8\% 2018).

Conclusion. In the Czech Republic, between 2012 and 2008, there was an increase in prevalence of patients with heart failure and concomitant diabetes mellitus, their proportion being similar. In correspondence with other registries, metformin was used mostly. A positive trend was observed in prescription of DDP-4 and SGLT-2 inhibitors, while there was a significant decrease in patients taking sulfonylureas.
\end{abstract}

Key words: diabetes mellitus, heart failure, pharmacotherapy, National Register of Paid Health Services (NRHZS)

Received: September 10, 2021; Revised: November 17, 2021; Accepted: November 23, 2021; Available online: December 8, 2021 https://doi.org/10.5507/bp.2021.069

(c) 2021 The Authors; https://creativecommons.org/licenses/by/4.0/

${ }^{a}$ Department of Medicine I - Cardiology, University Hospital Olomouc, Czech Republic

'Institute of Health Information and Statistics of the Czech Republic, Palackeho nam. 4, P.O.BOX 60, Prague, Czech Republic

'Institute of Biostatistics and Analyses, Faculty of Medicine, Masaryk University, Brno, Czech Republic

Corresponding author: Tomas Skala, e-mail: tomasskala@gmail.com

\section{INTRODUCTION}

Heart failure (HF) and diabetes mellitus (DM) are among the major diseases of civilization. Worldwide, there are an estimated 64.3 million people with HF (ref. ${ }^{1}$ ). $\mathrm{HF}$ is a heterogeneous syndrome that causes about $1-2 \%$ of all acute hospital hospitalizations. Over the age of 65 , it is the most common reason, with up to $20 \%$ of patients requiring subsequent rehospitalization for $\mathrm{HF}$ decompensation over the next 30 days $^{2,3}$. It is assumed that more than $10 \%$ of people in the population over 70 years have some form of HF. According to the most recent European Society of Cardiology (ESC) guidelines from 2016, we divide patients with HF into three subgroups according to left ventricular ejection fraction (LVEF), namely HF with reduced $\mathrm{LVEF}(\mathrm{HFrEF}<40 \%$ ), HF with mid-range $\mathrm{LVEF}$ (HFmEF 40-49\%) and with preserved LVEF (HFpEF> $50 \%)\left(\right.$ ref. $\left.^{4}\right)$. HF is a major socio-economic problem, especially in developed countries. In 2012, the cost of treatment worldwide was estimated at \$ 108 billion per annum ${ }^{5}$.

DM is a major global disease of civilization of the $21^{\text {st }}$ century and it is closely related to HF. It is estimated that about 463 million people in 2019 had some of its types. The trend is growing for both sexes. In 2030 it is estimated to be about 578 million people (10.2\% of the world's population) affected with DM worldwide. The basic groups are insulin-dependent type I DM (T1DM), type II DM (T2DM), which accounts for about 90\% (associated with insulin resistance) and so-called gestational diabetes (GDM). As many as half of the people with T2DM do not know about their disease. In 2019 alone, the number of deaths from diabetes and its complications reached about 4.2 million people. There are also significant financial costs, which reached $\$ 760$ billion per annum in 2019. It is estimated at up to $\$ 825$ billion per annum in 2030 (ref. $^{6}$ ).

The relationship between DM and HF development was observed in the 1970s in The Framingham Study. Heart failure was 2 times more common in diabetic men and even 5 times more common in women than in nondiabetic populations ${ }^{7}$. A key finding also for our analysis was that up to $44 \%$ of people hospitalized for $\mathrm{HF}$ also have DM $\left(\right.$ ref. $\left.^{8}\right)$.

Apart from DM, the factors contributing to the development of HF are mainly coronary artery disease, arterial hypertension and obesity. However, it is known that the development of HF can occur independently, even in the absence of the above comorbidities, only due to diabetic heart disease - we speak of the so-called diabetic cardio- 
myopathy. This unit was first described as early as 1972 $\left(\right.$ ref. ${ }^{9,10}$ ).

Although the pharmacological foundations of DM therapy were laid in the early mid- $20^{\text {th }}$ century, only new antidiabetics have shown a significant effect on reducing cardiovascular (CV) events, reducing hospitalization and the risk of developing $\mathrm{HF}$, while beneficially affecting overall mortality ${ }^{11,12}$.

\section{METHODOLOGY}

\section{Study design}

Retrospective observational analysis of data of used DM pharmacotherapy in patients with a concommitant diagnosis of HF, reported to the National Register of Paid Health Services (NRHZS) in the Czech Republic during the years 2012-2018.

\section{Patient group}

The patient cohort was selected from NRHZS data based on the currently reported DM diagnosis code (E10-E14) or other DM-specific diagnoses and the HF code (I50.x) according to the International Classification of Diseases (ICD-10). An exception are oncological diseases, the incidence of which is assessed on the basis of data from the National Cancer Registry (NOR).

Pharmacotherapy of DM was defined by reporting the drug with the appropriate Anatomical Therapeutic Chemical (ATC) classification code. Patients may have reported multiple different ATC codes during the year, but each patient is counted only once in a given year.

All published data were anonymized before the creation of the research database and complied with the regulations and applicable legislation - the Act on Health Services and the Conditions for their Provision (according to Act 372/2011 of the Collection).

\section{Study aim}

Analysis of trends in antidiabetic pharmacotherapy in patients with DM and concomitant HF.

\section{RESULTS}

In 2012, a total of 10.52 million people lived in the Czech Republic. 176,496 persons had HF, of which 75,022 (42.5\%) had both diagnoses (HF and DM). In 2018 , the prevalence of HF increased to 285,745 people out of a total of 10.65 million inhabitants. At the same time, HF and DM had 117,265 people (41\%). The development in the prevalence of HF and DM is shown in Table 1.

In the cohort of diabetics with HF in $2018(n=117,265)$, there were more men $(n=60,855)$ than women $(n=56,410)$. In contrast, the median age of women was higher $(79 ; 77.9$ $\pm 9.7)$ than men $(73 ; 72.7 \pm 10.2)$. In the age category over 75 years (in absolute and relative representation) women were more common. The distribution of gender and age is summarized in Fig. 1.

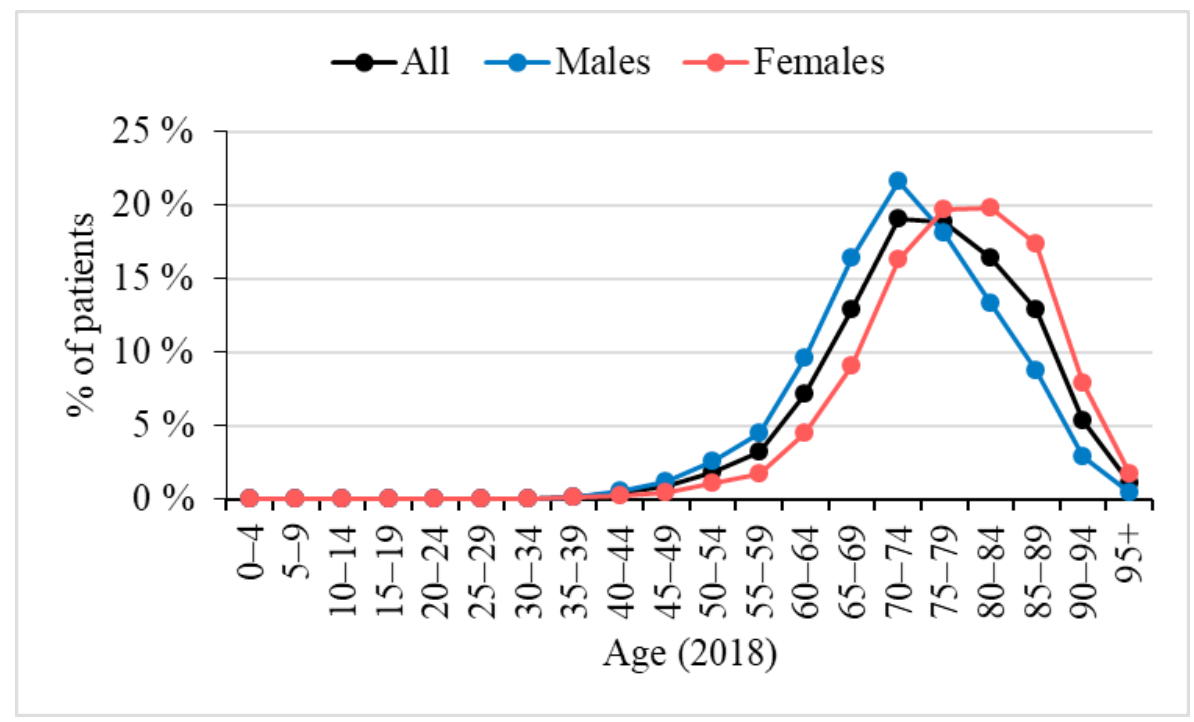

Fig. 1. Distribution of patients with HF and DM by sex and age in 2018.

Table 1. Prevalence and proportion of patients with $\mathrm{HF}$ and DM.

\begin{tabular}{lrrrrrrc}
\hline Cohort & \multicolumn{1}{c}{2012} & \multicolumn{1}{c}{2013} & 2014 & 2015 & 2016 & \multicolumn{1}{c}{2017} & 2018 \\
\hline Prevalence of HF & 176496 & 202135 & 223808 & 243683 & 256929 & 271907 & 285745 \\
Prevalence & 75022 & 84514 & 92987 & 100627 & 106114 & 111840 & 117265 \\
of HF+DM & $(42.5 \%)$ & $(41.8 \%)$ & $(41.5 \%)$ & $(41.3 \%)$ & $(41.3 \%)$ & $(41.1 \%)$ & $(41.0 \%)$ \\
\hline
\end{tabular}


In the analyzed patients $(n=117,265)$ with $\mathrm{HF}$ and DM (in 2018), the most common comorbidity was arterial hypertension $(97.1 \% ; n=113,910)$, followed by ischemic heart disease $(83.2 \% ; n=97,560)$. Half of the patients had atrial fibrillation $(51.5 \% ; n=60,434)$. A significant part was peripheral arterial disease $(34.5 \%)$ and renal failure (33.5\%). The others are listed in Table 2.

\section{Pharmacotherapy}

Between 2012 and 2018, 73.6\% of people with DM and concomitant HF were treated with at least one antidiabetic drug. The highest share of the prevalence of HF and DM was reached in the last monitored year $(75.7 \%$ in 2018; $n=88,749)$. An overview of the following years is summarized in Table 3.

The majority of used therapies were oral diabetics (PAD). In the study period (2012-2018), a total of 56.2\% of subjects with antidiabetic therapy (i.e. $43.4 \%$ of patients with HF and DM in 2018) used them alone (including subcutaneously administered glucagon-like receptor

Table 2. Comorbidities in patients with HF and DM in 2018

$$
(n=117,265) \text {. }
$$

\begin{tabular}{lcr}
\hline Comorbidities & $\begin{array}{c}\text { \% of all HF }+ \\
\text { DM }\end{array}$ & Total \\
\hline Arterial hypertension & $97.1 \%$ & 113910 \\
Ischemic heart diseases & $83.2 \%$ & 97560 \\
Dyslipoproteinemias & $58.5 \%$ & 68585 \\
Atrial fibrillation & $51.5 \%$ & 60434 \\
Peripheral artery disease & $34.5 \%$ & 40508 \\
Chronic obstructive pulmonary & $34.4 \%$ & 40304 \\
disease & & \\
Renal failure & $33.5 \%$ & 39333 \\
Malignant tumors & $22.3 \%$ & 26162 \\
Stroke & $19.4 \%$ & 22804 \\
Dementia & $12.3 \%$ & 14372 \\
Sleep apnoea & $3.6 \%$ & 4178 \\
\hline
\end{tabular}

1-GLP1- $\alpha$ receptor agonists). Together, PAD (including when combined with insulin) was used by $59.4 \%$ of patients with HF and DM in 2018.

Treatment with insulin alone or insulin analogues accounted for (in 2012-2018) $24.1 \%$ of antidiabetic therapy (i.e. $16.3 \%$ of the prevalence of HF and DM in 2018). Overall, $32.3 \%$ of people diagnosed with HF and DM in 2018 had insulin and insulin analogues (including patients with PAD combination therapy).

Persons with antidiabetic therapy were characterized by a positive trend in the use of PAD (54.9\% 2012; 57.3\% 2018 ) and combination therapy (18.7\% 2012; 21.1\% 2018), on the contrary, a decrease in solo use of insulins and insulin analogues $(26.5 \%$ 2012; $21.6 \%$ in 2018). The development between 2012-2018 is shown in Table 4.

The most used drug in the observed period was classical metformin with an average proportion of $36.9 \%$ (34.3\% in 2012; 38.3\% 2018). Metformin (including its fixed combinations) accounted for $36.5 \%$ of antidiabetic treatment in patients with HF and DM in 2012. In the following years, in addition to the introduction of new fixed combinations, this ratio increased $(38.1 \% 2013 ; 40.3 \%$ $2014 ; 41.9 \% 2015 ; 43.3 \% 2016 ; 44.1 \% 2017$ and $45.6 \%$ 2018).

The main fixed combination with metformin was sitagliptin and vildagliptin (both $1.9 \%$ in 2018). The smallest proportion of fixed combinations of metformin was canagliflozin and saxagliptin (both $0.1 \%$ in 2018). In the PAD group, a downward trend for sulfonylurea derivatives was evident. Specifically, gliclazide (13.0\% 2012; $10.3 \%$ in 2018 ) followed by glimepiride (12.9\% 2012; 9.0\% 2018). Linagliptin from the group of dipeptidyl peptidase 4 (DDP-4) inhibitors increased significantly (0.7\% 2012; $6.8 \% 2018$ ). Only $0.7 \%$ of patients with HF and DM used GLP-1a, of which the most represented in 2018 was liraglutide $(0.4 \%)$. The number of persons using antidiabetics (excluding insulin and insulin analogues) and their share of the prevalence of HF and DM is given in Table 5.

Table 3. Antidiabetic therapy in patients with HF and DM.

\begin{tabular}{|c|c|c|c|c|c|c|c|}
\hline Cohort & 2012 & 2013 & 2014 & 2015 & 2016 & 2017 & 2018 \\
\hline Patients with HF + DM & 75022 & 84514 & 92987 & 100627 & 106114 & 111840 & 117265 \\
\hline Patients with antidiabetics & 52846 & 60834 & 68197 & 74411 & 79599 & 84147 & 88749 \\
\hline$\%$ of prevalence $\mathrm{HF}+\mathrm{DM}$ & $70.4 \%$ & $72.0 \%$ & $73.3 \%$ & $73.9 \%$ & $75.0 \%$ & $75.2 \%$ & $75.7 \%$ \\
\hline
\end{tabular}

Table 4. Type of therapy in patients with HF and DM treated with antidiabetic therapy.

\begin{tabular}{|c|c|c|c|c|c|c|c|c|c|c|c|c|c|c|}
\hline \multirow[b]{2}{*}{ Cohort } & \multicolumn{2}{|c|}{2012} & \multicolumn{2}{|c|}{2013} & \multicolumn{2}{|c|}{2014} & \multicolumn{2}{|c|}{2015} & \multicolumn{2}{|c|}{2016} & \multicolumn{2}{|c|}{2017} & \multicolumn{2}{|c|}{2018} \\
\hline & Total & $\%$ & Total & $\%$ & Total & $\%$ & Total & $\%$ & Total & $\%$ & Total & $\%$ & Total & $\%$ \\
\hline $\begin{array}{l}\text { Insulin and insulin } \\
\text { analogs }\end{array}$ & 13978 & 26.4 & 15884 & 26.1 & 17018 & 25.0 & 17772 & 23.9 & 18576 & 23.3 & 18954 & 22.5 & 19147 & 21.6 \\
\hline $\begin{array}{l}\text { Peroral } \\
\text { antidiabetics }\end{array}$ & 28994 & 54.9 & 33699 & 55.4 & 38162 & 56.0 & 42029 & 56.5 & 45090 & 56.6 & 47757 & 56.8 & 50878 & 57.3 \\
\hline $\begin{array}{l}\text { Combination } \\
\text { therapy }\end{array}$ & 9874 & 18.7 & 11251 & 18.5 & 13017 & 19.0 & 14610 & 19.6 & 15933 & 20.1 & 17436 & 20.7 & 18724 & 21.1 \\
\hline
\end{tabular}




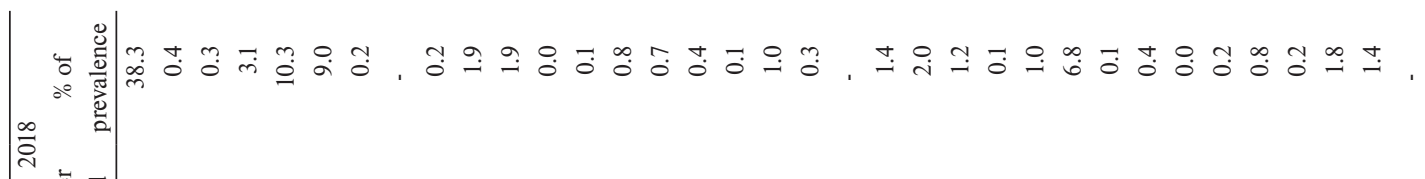

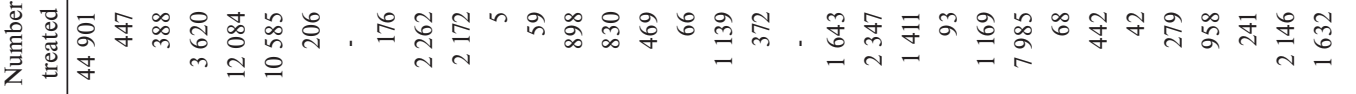

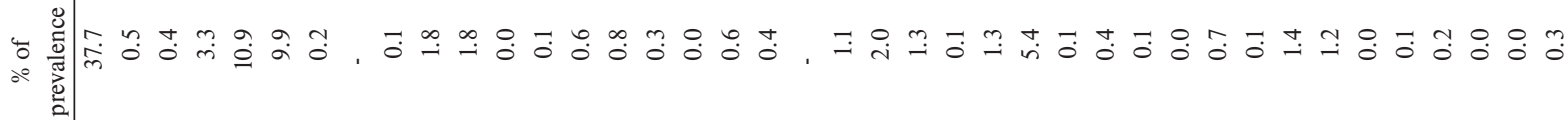
ते

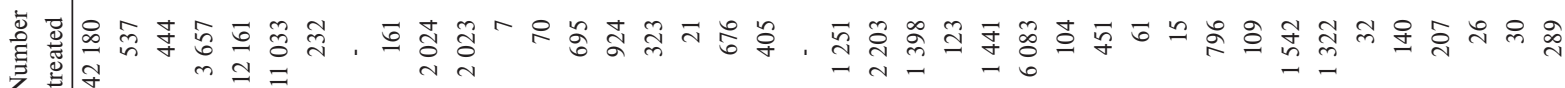

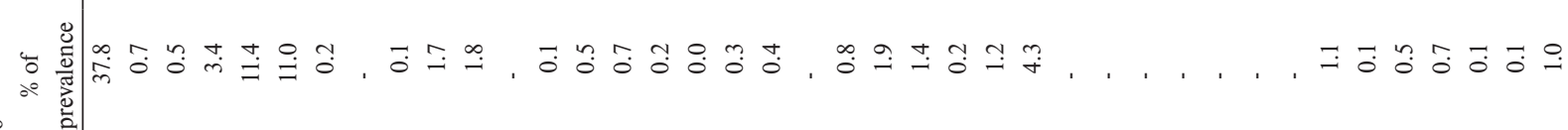
ํำ

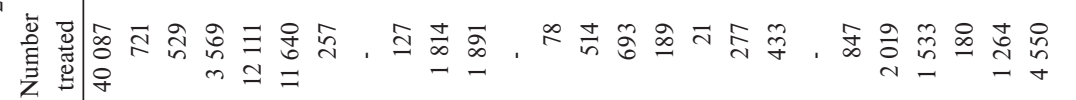

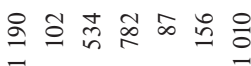

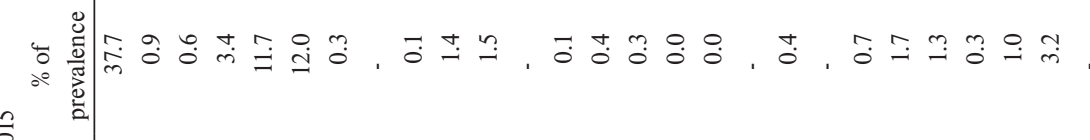

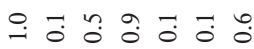
iे

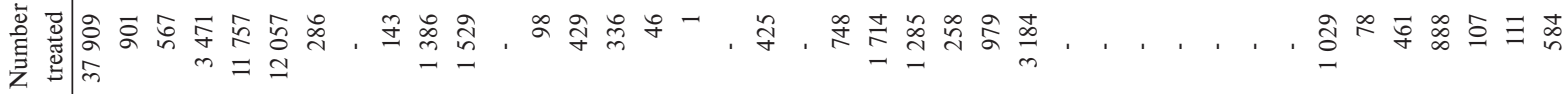

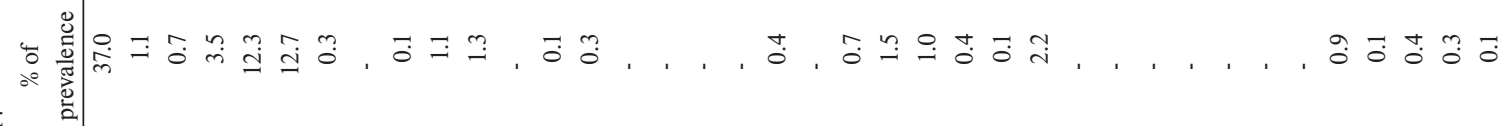
突

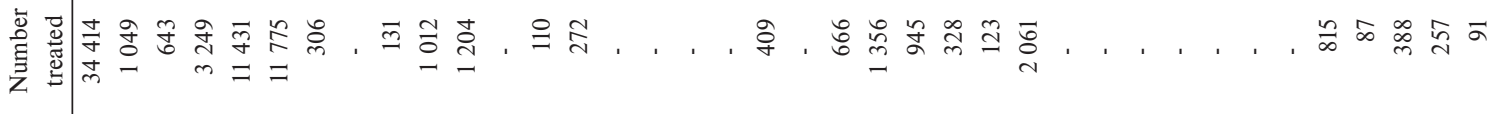

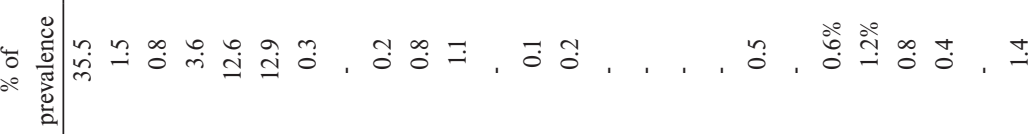
$\stackrel{0}{0} \ddot{0} \stackrel{0}{0}$ ते

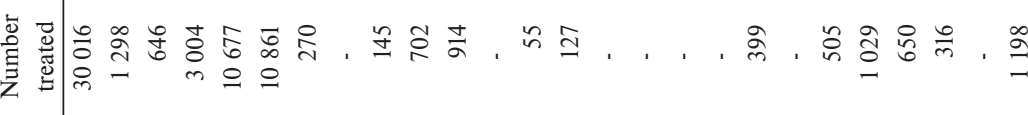

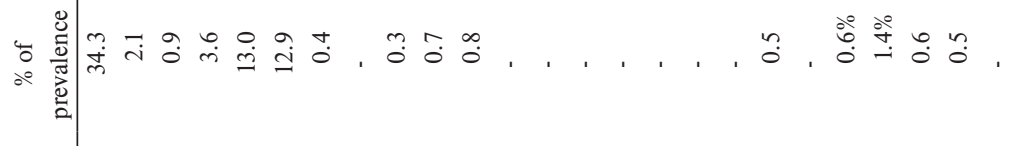

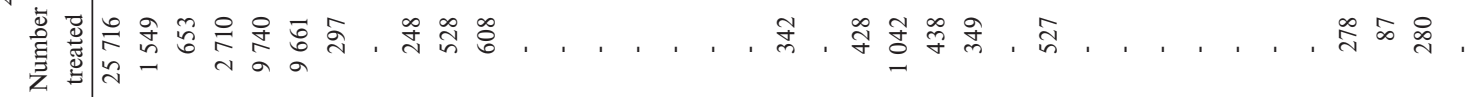

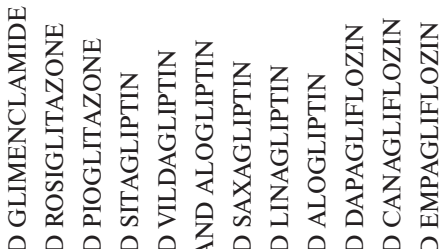

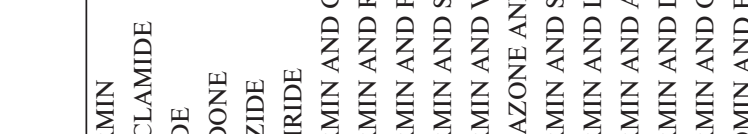

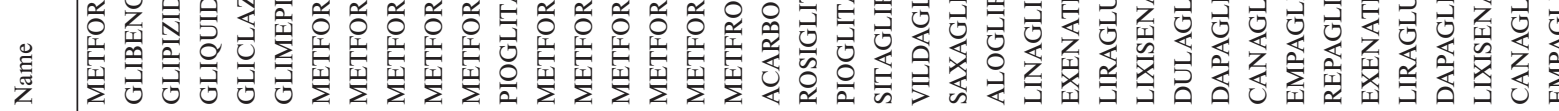

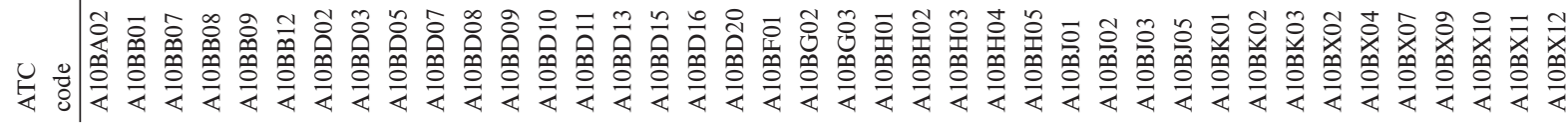




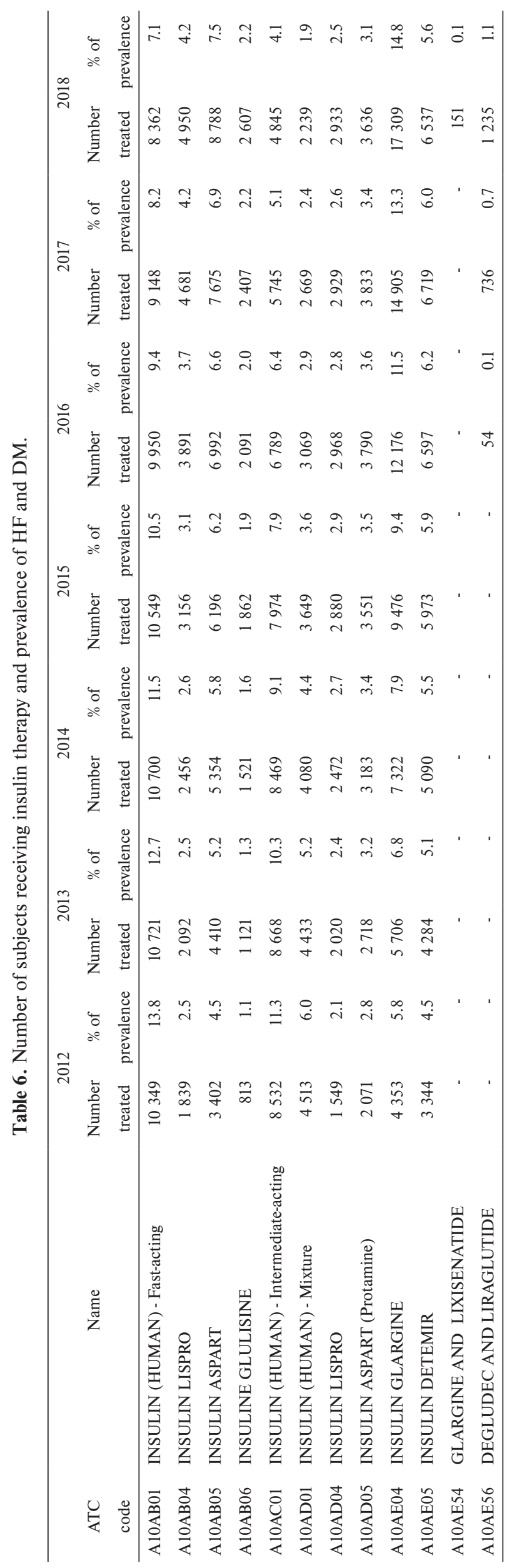

Of insulin and its analogue, glargine was the most represented (5.8\% 2012; 14.8\% 2018). A similar positive trend was generated by the fast-acting insulin analogue - aspart (4.5\% 2012; 7.5\% in 2018). The opposite trend was observed with fast-acting human insulin (13.8\% 2012; $7.1 \% 2018)$ and intermediate-acting human insulin (11.3\% 2012; 4.1\% 2018).

Since 2016, we have seen a growing number of users of the fixed combination degludec / liraglutide $(0.1 \% 2016$; $1.1 \%$ 2018). The number of people using insulin and analogues from the proportion of patients with HF and DM is shown in Table 6.

\section{DISCUSSION}

In 2018, there were 117,245 patients with DM and concomitant HF in the Czech Republic, which is $41.0 \%$ of diagnosed patients with HF. For comparison, in the Get With the Guidelines-Heart Failure Registry (GWTG-HF), DM was present in $44.0 \%$ of hospitalized patients with HF between 2005 and 2015 (overall for all LVEFs) ( ref. $^{8}$ ).

Based on a joint consensus of the American Diabetes Association (ADA) and the European Association for the Study of Diabetes (EASD), metformin remains the drug of first choice (in general) in patients with T2DM. The advantage of this treatment is easy availability, low cost, minimal risk of hypoglycemia and is not accompanied by weight gain. However, despite modern pharmacotherapy, lifestyle change plays a key role in patients with T2DM (ref. ${ }^{13}$ ). The recommended treatment for people with T2DM and concomitant HF based on a joint decision of the European Society of Cardiology (ESC) and the European Diabetes Society (EAD) of 2019 includes metfomin and, in this indication, SGLT-2 inhibitors. In contrast, pioglitazone, rosiglitazone and saxagliptin are not recommended for HF and DM (class / level III / B) $\left(\right.$ ref. $\left.^{14}\right)$.

Metformin reached the highest prevalence in patients with HF and DM in our analysis, which corresponds to other foreign registries. However, compared to the Diabetes Collaborative Registry (DCR), it was less represented (45.6\% 2018 vs 57.8\%) (ref. $\left.{ }^{15}\right)$. Metformin treatment may be recommended in stable or moderate renal impairment (i.e. eGFR $>30 \mathrm{~mL} / \mathrm{min} / 1.73 \mathrm{~m}^{2}$ ). In the light of new data the previously reported risk of developing lactic acidosis is perceived as minimal ${ }^{16}$. The benefit of metformin in patients with T2DM has been demonstrated in the past by a large United Kingsdom Prospective Diabetes Study (UKPDS), but data from large RCTs on its contribution to reducing the risk of heart failure and/or re-hospitalization in patients with HF and T2DM are still lacking. However, its long-established safety in comparison with other antidiabetic drugs cannot be questioned ${ }^{17,18}$.

The role of sodium-glucose co-transporter 2 (SGLT-2) inhibitors is of new and fundamental importance in the therapy of patients with HF and DM. They have been available in the Czech Republic since 2014 and their share is growing every year. In 2018, empagliflozin was 
the most represented in our country. Overall, SGLT-2 inhibitor therapy (without fixed combination with metformin) accounted for $2.8 \%$ (vs $2.5 \%$ in the DCR registry). Empagliflozin alone reduced HF hospitalization by $35 \%$ compared to placebo in the EMPA-REG OUTCOME study in subjects with T2DM. Reduced all-cause death by $32 \%$ (ref. ${ }^{19}$ ). Cannagliflozin also significantly reduced the risk of hospitalization for HF by $32 \%$ in the CANVAS study $^{20}$. Another suitable SGLT-2 in the treatment of HF and DM (based on the ESC / EAD recommendation of 2019) is dapagliflozin. In the DECLARE-TIMI study 58, dapagliflozin reduced the risk of hospitalizations for HF (ref. ${ }^{21}$ ). The key finding was that dapagliflozin (in DAPA$\mathrm{HF}$ ) in patients with HFrEF reduced the risk of hospitalization for HF independent of the presence of DM, which opens up completely new possibilities and indications for SGLT-2 inhibitors in the treatment of chronic HF in the future ${ }^{22}$. The second, very significant aspect of SGLT-2 inhibitor treatment is confirmed nephroprotectivity. In our cohort of patients with HF and DM, up to a third of patients had a record of renal failure $(33.5 \%$ in 2018). A significant renoprotective effect was confirmed by the CREDENCE study (with canagliflozin), which additionally demonstrated the efficacy of canagliflozin up to eGFR $30 \mathrm{~mL} / \mathrm{min} / 1.73 \mathrm{~m}^{2}$ (ref. ${ }^{23}$ ). Significant improvement in renal function while reducing overall mortality in patients with chronic renal insufficiency was also demonstrated by dapagliflozin in the DAPA-CKD study, even independently of the presence of DM $\left(\right.$ ref. $\left.^{24}\right)$.

A significant (international) decrease in prescription was observed for sulfonylurea derivatives (SU derivatives) $\left(\right.$ ref. $\left.{ }^{25}\right)$. In our analysis for 2018 , they accounted for $23.1 \%$ of the prevalence of HF and DM (predominantly represented by glimepiride and gliclazide). Based on the UGDP study with tolbutamide, SU derivatives have been associated with the risk of death from CHD causes since 1960. From today's perspective, the study had significant methodological limitations (randomization method, $20 \%$ non-compliance, and others) (ref. ${ }^{26}$ ). Several large retrospective analyzes confirmed a higher risk of hospitalization for $\mathrm{HF}$ in SU derivatives compared to metformin, however, in the CAROLINA study (linagliptin vs glimepiride) glimepiride was non-inferior in CV safety, only a higher proportion of hypoglycemia known ${ }^{27,28}$.

Thiazolidinedione drugs, pioglitazone registered in our country, were used by $0.6 \%$ of patients with HF and DM in 2012 (1.4\% in 2018), despite the known risk of fluid retention and the possibility of worsening of HF. Therefore, neither pioglitazone nor rosiglitazone are recommended in the treatment of DM in patients at risk of developing or pre-existing HF (ref. ${ }^{14}$ ).

Similar to thiazolidindiones, saxagliptin from the DPP-4 family may worsen HF (SAVOR-TIMI study 53) $\left(\right.$ ref. $\left.^{29}\right)$. In our analysis, its trend in prescription was declining. However, linagliptin (CARMELINA study) and sitagaliptin (TECOS study) from the same group did not show a significant difference in HF-related outcome compared to placebo $^{30,31}$. They can therefore be recommended in patients with T2DM and HF ( ref. $^{14}$ ). The most significant trend from DPP-4 was recorded by the mentioned linagliptin, both alone and in fixed combination with metformin. Due to its minimal renal clearance, linagliptin is also suitable for patients with advanced renal failure, including dialysis patients, where treatment options for PAD are severely limited. The proportion of DDP-4 in our sample (incl. fixed combinations) was similar to the DCR register (16.5\% vs $14.6 \%$ DCR in 2018).

Only a small proportion of treatment in patients with HF and DM between 2012 and 2018 were GLP-1, despite having a neutral effect on the risk of hospitalization for $\mathrm{HF}$ in their placebo-controlled studies. Subcutaneously administered lixisenatide, liraglutide, semaglutide, dulaglutide and exenatide are therefore also appropriate in patients with HF and DM (ref. ${ }^{14}$ ). In addition, liraglutide, semaglutide and dulaglutide can be used in advanced renal failure (eGFR> $15 \mathrm{ml} / \mathrm{min} / 1.73 \mathrm{~m} 2$ ). Their small effect on lowering systolic blood pressure (SBP) is also known, which is especially advantageous for patients with arterial hypertension (97.1\% in our analysis). Liraglutide and semaglutide therapy reduces the risk of major CV events in individuals with T2DM and at the same time a high CV risk ${ }^{32}$.

A significant proportion of patients with $\mathrm{HF}$ and DM require insulin therapy to achieve adequate glycemic control. Insulin and analogues are necessary where PAD combination therapy is already insufficient or directly contraindicated. Insulin resistance is known to indirectly contribute to HF progression. The analysis of the TOPCAT study showed a significantly higher risk of hospitalization for heart failure in insulin-treated $\mathrm{HFpEF}$ patients than in the PAD group (37.0\% vs $22.0 \%$ per year) $\left(\right.$ ref. $\left.{ }^{33}\right)$. However, it is clear that subjects initiating insulin therapy have a higher prevalence of CVD, chronic renal failure, and other significant comorbidities overall compared to the PAD initial therapy group ${ }^{34}$. In our cohort (in 2018), $42.7 \%$ of treated patients (i.e. $32.3 \%$ of the proportion of patients with HF and DM) used insulin and its analogues (in monotherapy and / or in combination therapy with PAD). For comparison in the DCR register it was $40.9 \%$. The long-acting insulin analogue glargine had the highest proportion, whose CV safety was confirmed by a randomized controlled trial (ORIGIN) $\left(\right.$ ref. $\left.{ }^{35}\right)$.

\section{Study limitations}

A major limitation is the absence of basic knowledge about heart failure, i.e. LVEF, HF etiology, NYHA functional class and natriuretic peptide levels. With regard to the number of patients, the selection bias was reduced, but the accuracy of the entered data and diagnoses cannot be verified. There is a lack of further data on individuals who were reported at the same time as a code for HF and DM, but subsequently did not show any antidiabetic therapy with the ATC code. Patients with HF and T1DM or T2DM were not separately evaluated in the study, whereas a significantly different ratio of antidiabetic therapy (PAD vs insulin) can be expected. There is a lack of data on cured patients over the years. Patients may have been diagnosed with heart failure, for example, in 2012, but already in 2013 they did not have to meet the symptoms and criteria for this diagnosis, although they could still 
be kept under this diagnosis for the following years. The patient could have reported several different ATC codes in a given year, therefore, for example, the sum of individual ATC insulins and analogues exceeds the number of patients treated with insulin therapy (each patient is counted only once in a given year). The analysis does not specify and evaluate the cohort of patients who received combination therapy (i.e. insulin and PAD at the same time) in one year, so it is not possible to determine which antidiabetics were most often used in this indication. In 2017, there was a change in the ATC of SGLT-2 inhibitors and GLP-1 antagonists, so one drug is listed in the table twice (until 2017 and from 2017).

\section{CONCLUSION}

In the Czech Republic, between 2012 and 2008, there was an evident increase in prevalence of patients with heart failure and concomitant diabetes mellitus, their proportion being similar. In correspondence with other foreign registries, the most widely used antidiabetic drug was metformin. A positive trend was observed in the prescription of DDP-4 and SGLT-2 inhibitors, while there was a significant decrease in patients taking sulfonylureas.

Author contributions: All authors contributed equally to preparing the manuscript.

Conflict of interest statement: None declared.

\section{REFERENCES}

1. GBD 2017 Disease and Injury Incidence and Prevalence Collaborators. Global, regional, and national incidence, prevalence, and years lived with disability for 354 diseases and injuries for 195 countries and territories, 1990-2017: a systematic analysis for the Global Burden of Disease Study 2017. Lancet 2018;392(10159):1789-1858.

2. Alla F, Zannad F, Filippatos G. Epidemiology of acute heart failure syndromes. Heart Fail Rev 2007;12(2):91-5.

3. Nichols GA, Reynolds K, Kimes TM, Rosales AG, Chan WW. Comparison of Risk of Re-hospitalization, All-Cause Mortality, and Medical Care Resource Utilization in Patients With Heart Failure and Preserved Versus Reduced Ejection Fraction. Am J Cardiol 2015;116(7):1088-92.

4. Ponikowski P, Voors AA, Anker SD, Bueno H, Cleland JGF, Coats AJS, Falk V, González-Juanatey JR, Harjola VP, Jankowska EA, Jessup M, Linde C, Nihoyannopoulos P, Parissis JT, Pieske B, Riley JP, Rosano GMC, Ruilope LM, Ruschitzka F, Rutten FH, van der Meer P; ESC Scientific Document Group. 2016 ESC Guidelines for the diagnosis and treatment of acute and chronic heart failure: The Task Force for the diagnosis and treatment of acute and chronic heart failure of the European Society of Cardiology (ESC)Developed with the special contribution of the Heart Failure Association (HFA) of the ESC. Eur Heart J 2016 14;37(27):2129-200.

5. Cook C, Cole G, Asaria P, Jabbour R, Francis DP. The annual global economic burden of heart failure. Int J Cardiol 2014;171(3):368-76.

6. International Diabetes Federation. IDF Diabetes Atlas, 9th edn. Brussels, Belgium: International Diabetes Federation, 2019.

7. Kannel WB, McGee DL. Diabetes and cardiovascular disease. The Framingham study. JAMA 1979;241(19):2035-8.

8. Echouffo-Tcheugui JB, Xu H, DeVore AD, Schulte PJ, Butler J, Yancy CW, Bhatt DL, Hernandez AF, Heidenreich PA, Fonarow GC. Temporal trends and factors associated with diabetes mellitus among patients hospitalized with heart failure: Findings from Get With The Guidelines-Heart Failure registry. Am Heart J 2016;182:9-20.
9. Bozkurt B, Aguilar D, Deswal A, Dunbar SB, Francis GS, Horwich T, Jessup M, Kosiborod M, Pritchett AM, Ramasubbu K, Rosendorff C, Yancy C; American Heart Association Heart Failure and Transplantation Committee of the Council on Clinical Cardiology; Council on Cardiovascular Surgery and Anesthesia; Council on Cardiovascular and Stroke Nursing; Council on Hypertension; and Council on Quality and Outcomes Research. Contributory Risk and Management of Comorbidities of Hypertension, Obesity, Diabetes Mellitus, Hyperlipidemia, and Metabolic Syndrome in Chronic Heart Failure: A Scientific Statement From the American Heart Association. Circulation 2016;134(23):e535-e578.

10. Rubler S, Dlugash J, Yuceoglu YZ, Kumral T, Branwood AW, Grishman A. New type of cardiomyopathy associated with diabetic glomerulosclerosis. Am J Cardiol 1972;30(6):595-602.

11. White JR Jr. A Brief History of the Development of Diabetes Medications. Diabetes Spectr 2014;27(2):82-6.

12. Home P. Cardiovascular outcome trials of glucose-lowering medications: an update. Diabetologia 2019;62(3):357-69.

13. Buse JB, Wexler DJ, Tsapas A, Rossing P, Mingrone G, Mathieu C, D'Alessio DA, Davies MJ. 2019 update to: Management of hyperglycaemia in type 2 diabetes, 2018. A consensus report by the American Diabetes Association (ADA) and the European Association for the Study of Diabetes (EASD). Diabetologia 2020;63(2):221-28.

14. Cosentino F, Grant PJ, Aboyans V, Bailey CJ, Ceriello A, Delgado V, Federici M, Filippatos G, Grobbee DE, Hansen TB, Huikuri HV, Johansson I, Jüni P, Lettino M, Marx N, Mellbin LG, Östgren CJ, Rocca B, Roffi M, Sattar N, Seferović PM, Sousa-Uva M, Valensi P, Wheeler DC; ESC Scientific Document Group. 2019 ESC Guidelines on diabetes, pre-diabetes, and cardiovascular diseases developed in collaboration with the EASD. Eur Heart J 2020;41(2):255-323.

15. Arnold SV, Echouffo-Tcheugui JB, Lam CSP, Inzucchi SE, Tang F, McGuire DK, Goyal A, MaddoxTM, Sperling LS, Fonarow GC, Masoudi FA, Kosiborod M. Patterns of glucose-lowering medication use in patients with type 2 diabetes and heart failure. Insights from the Diabetes Collaborative Registry (DCR). Am Heart J 2018;203:25-9.

16. MacDonald MR, Petrie MC, Hawkins NM, Petrie JR, Fisher M, McKelvie R, Aguilar D, Krum H, McMurray JJ. Diabetes, left ventricular systolic dysfunction, and chronic heart failure. Eur Heart J 2008;29(10):122440.

17. UK Prospective Diabetes Study (UKPDS) Group. Effect of intensive blood-glucose control with metformin on complications in overweight patients with type 2 diabetes (UKPDS 34). Lancet 1998;352(9131):854-65.

18. Packer M. Is metformin beneficial for heart failure in patients with type 2 diabetes? Diabetes Res Clin Pract 2018;136:168-70.

19. Fitchett D, Zinman B, Wanner C, Lachin JM, Hantel S, Salsali A, Johansen OE, Woerle HJ, BroedI UC, Inzucchi SE; EMPA-REG OUTCOME $^{\circledR}$ trial investigators. Heart failure outcomes with empagliflozin in patients with type 2 diabetes at high cardiovascular risk: results of the EMPA-REG OUTCOME ${ }^{\circledR}$ trial. Eur Heart J 2016;37(19):1526-34.

20. Mahaffey KW, Neal B, Perkovic V, de Zeeuw D, Fulcher G, Erondu N, Shaw W, Fabbrini E, Sun T, Li Q, Desai M, Matthews DR; CANVAS Program Collaborative Group. Canagliflozin for Primary and Secondary Prevention of Cardiovascular Events: Results From the CANVAS Program (Canagliflozin Cardiovascular Assessment Study). Circulation 2018;137(4):323-34.

21. Wiviott SD, Raz I, Bonaca MP, Mosenzon O, Kato ET, Cahn A Silverman MG, Zelniker TA, Kuder JF, Murphy SA, Bhatt DL, Leiter LA, McGuire DK, Wilding JPH, Ruff CT, Gause-Nilsson IAM, Fredriksson M, Johansson PA, Langkilde AM, Sabatine MS; DECLARE-TIMI 58 Investigators. Dapagliflozin and Cardiovascular Outcomes in Type 2 Diabetes. N Engl J Med 2019;380(4):347-57.

22. McMurray JJV, Solomon SD, Inzucchi SE, Køber L, Kosiborod MN, Martinez FA, Ponikowski P, Sabatine MS, Anand IS, Bělohlávek J, Böhm M, Chiang CE, Chopra VK, de Boer RA, Desai AS, Diez M, Drozdz J, Dukát A, Ge J, Howlett JG, Katova T, Kitakaze M, Ljungman CEA, Merkely B, Nicolau JC, O'Meara E, Petrie MC, Vinh PN, Schou M, Tereshchenko S, Verma S, Held C, DeMets DL, Docherty KF, Jhund PS, Bengtsson O, Sjöstrand M, Langkilde AM; DAPA-HF Trial Committees and Investigators. Dapagliflozin in Patients with Heart Failure and Reduced Ejection Fraction. N Engl J Med 2019;381(21):1995-2008.

23. Jardine MJ, Mahaffey KW, Neal B, Agarwal R, Bakris GL, Brenner BM, Bull S, Cannon CP, Charytan DM, de Zeeuw D, Edwards R, Greene 
T, Heerspink HJL, Levin A, Pollock C, Wheeler DC, Xie J, Zhang $\mathrm{H}_{\text {, }}$ Zinman B, Desai M, Perkovic V; CREDENCE study investigators. The Canagliflozin and Renal Endpoints in Diabetes with Established Nephropathy Clinical Evaluation (CREDENCE) Study Rationale, Design, and Baseline Characteristics. Am J Nephrol 2017;46(6):46272.

24. Wheeler DC, Stefansson BV, Batiushin M, Bilchenko O, Cherney DZI, Chertow GM, Douthat W, Dwyer JP, Escudero E, Pecoits-Filho R, Furuland H, Górriz JL, Greene T, Haller H, Hou FF, Kang SW, Isidto R, Khullar D, Mark PB, McMurray JJV, Kashihara N, Nowicki M, Persson F, Correa-Rotter R, Rossing P, Toto RD, Umanath K, Van Bui P, Wittmann I, Lindberg M, Sjöström CD, Langkilde AM, Heerspink HJL. The dapagliflozin and prevention of adverse outcomes in chronic kidney disease (DAPA-CKD) trial: baseline characteristics. Nephrol Dial Transplant 2020;35(10):1700-11.

25. Ramzan S, Timmins P, Hasan SS, Babar ZU. Trends in global prescribing of antidiabetic medicines in primary care: A systematic review of literature between 2000-2018. Prim Care Diabetes 2019;13(5):40921.

26. Blackburn H, Jacobs DR Jr. The University Group Diabetes Program 1961-1978: pioneering randomized controlled trial. Int J Epidemiol 2017;46(5):1354-64.

27. Nassif M, Kosiborod M. Effect of glucose-lowering therapies on heart failure. Nat Rev Cardiol 2018;15(5):282-91.

28. Rosenstock J, Kahn SE, Johansen OE, Zinman B, Espeland MA, Woerle HJ, Pfarr E, Keller A, Mattheus M, Baanstra D, Meinicke T, George JT, von Eynatten M, McGuire DK, Marx N; CAROLINA Investigators. Effect of Linagliptin vs Glimepiride on Major Adverse Cardiovascular Outcomes in Patients With Type 2 Diabetes: The CAROLINA Randomized Clinical Trial JAMA 2019;322(12):1155-66.

29. Udell JA, Bhatt DL, Braunwald E, Cavender MA, Mosenzon O, Steg PG, Davidson JA, Nicolau JC, Corbalan R, Hirshberg B, Frederich R, Im K, Umez-Eronini AA, He P, McGuire DK, Leiter LA, Raz I, Scirica BM; SAVOR-TIMI 53 Steering Committee and Investigators. Saxagliptin and cardiovascular outcomes in patients with type 2 diabetes and moderate or severe renal impairment: observations from the SAVORTIMI 53 Trial. Diabetes Care 2015;38(4):696-705.

30. Rosenstock J, Perkovic V, Johansen OE, Cooper ME, Kahn SE, Marx N, Alexander JH, Pencina M, Toto RD, Wanner C, Zinman B, Woerle HJ, Baanstra D, Pfarr E, Schnaidt S, Meinicke T, George JT, von Eynatten M, McGuire DK; CARMELINA Investigators. Effect of Linagliptin vs Placebo on Major Cardiovascular Events in Adults With Type 2 Diabetes and High Cardiovascular and Renal Risk: The CARMELINA Randomized Clinical Trial. JAMA 2019;321(1):69-79.

31. Green JB, Bethel MA, Armstrong PW, Buse JB, Engel SS, Garg J, Josse R, Kaufman KD, Koglin J, Korn S, Lachin JM, McGuire DK, Pencina MJ, Standl E, Stein PP, Suryawanshi S, Van de Werf F, Peterson ED, Holman RR; TECOS Study Group. Effect of Sitagliptin on Cardiovascular Outcomes in Type 2 Diabetes. N Engl J Med 2015;373(3):232-42.

32. Nauck MA, Meier JJ, Cavender MA, Abd El Aziz M, Drucker DJ. Cardiovascular Actions and Clinical Outcomes With Glucagon-Like Peptide-1 Receptor Agonists and Dipeptidyl Peptidase-4 Inhibitors. Circulation 2017;136(9):849-70.

33. Huynh T, Harty BJ, Claggett B, Fleg JL, McKinlay SM, Anand IS, Lewis EF, Joseph J, Desai AS, Sweitzer NK, EileenO'Meara, Pitt B, Pfeffer MA, Rouleau JL. Comparison of Outcomes in Patients With Diabetes Mellitus Treated With Versus Without Insulin + Heart Failure With Preserved Left Ventricular Ejection Fraction (from the TOPCAT Study). Am J Cardiol 2019;123(4):611-17.

34. Montvida O, Shaw J, Atherton JJ, Stringer F, Paul SK. Long-term Trends in Antidiabetes Drug Usage in the U.S.: Real-world Evidence in Patients Newly Diagnosed With Type 2 Diabetes. Diabetes Care 2018;41(1):69-78.

35. Gerstein HC, Bosch J, Dagenais GR, Díaz R, Jung H, Maggioni AP, Pogue J, Probstfield J, Ramachandran A, Riddle MC, Rydén LE, Yusuf $\mathrm{S}$. Basal insulin and cardiovascular and other outcomes in dysglycemia. N Engl J Med 2012;367(4):319-28. 